\title{
Real-time Analysis of Impedance Alterations by the Effects of Vanadium Pentoxide on Several Carcinoma Cell Lines
}

\author{
Vanadyum Pentoksidin Çeşitli Kanser Hücre Hatlarındaki Etkilerinin \\ Empedans Değişiklikleri ile Gerçek Zamanlı Analizi
}

\author{
(D) Ebru ÖZTÜRK ${ }^{1 *}$, (D) Ayșe Kübra KARABOĞA ARSLAN', (D) Alim Hüseyin DOKUMACl², (D) Mükerrem Betül YERER \\ 'Erciyes University, Faculty of Pharmacy, Department of Pharmacology, Kayseri, Turkey \\ Erciyes University, Graduate School of Health Sciences, Department of Pharmacology, Kayseri, Turkey
}

\begin{abstract}
Objectives: Vanadium compounds have various pharmacologic effects and all available evidence reveals that the effects of vanadium compounds depend on many factors, mainly on the type of cells and dose. The proapoptotic or antiapoptotic effect of vanadium compounds depends strongly on the cell type.

Materials and Methods: In this study, the effects of vanadium pentoxide $\left(\mathrm{V}_{2} \mathrm{O}_{5}\right)$ were investigated using several tumor cell lines: a colorectal cancer cell line (Colo-205), a human breast adenocarcinoma cell line (MCF-7), and a normal human fibroblast cell line. Five different concentrations of $\mathrm{V}_{2} \mathrm{O}_{5}$ between 25-200 $\mu \mathrm{M}$ were applied on the cells and xCELLigence real-time cell analysis was conducted to evaluate the impedance alterations. This study is the first to show $\mathrm{V}_{2} \mathrm{O}_{5}$ 's effects on Colo-205 and MCF-7 and human fibroblast cell lines in a real-time manner.

Results: In the Colo-205 cell line, cell index $(\mathrm{Cl})$ alterations decreased slightly at $25 \mu \mathrm{M}$ and $50 \mu \mathrm{M}$, and increased at $100 \mu \mathrm{M}, 150 \mu \mathrm{M}$ and $200 \mu \mathrm{M}$ concentrations. In the MCF-7 cell line, $\mathrm{Cl}$ alterations increased at all concentrations compared with the untreated control. However, in the healthy fibroblast cell line, the $\mathrm{Cl}$ alterations decreased at all concentrations compared with the untreated control, which limits the use of $\mathrm{V}_{2} \mathrm{O}_{5}$ for its cytotoxic effect in vivo.

Conclusion: The combination of conventional anticancer drugs can be used to increase the effectiveness and reduce the adverse effects of these drugs considering stages of cancer and cancer type. Our results suggest that $\mathrm{V}_{2} \mathrm{O}_{5}$ has disparate effects on several cancer cells at different concentrations.
\end{abstract}

Key words: xCELLigence, Colo-205, MCF-7, human fibroblast cell line, vanadium pentoxide

ÖZ

Amaç: Vanadyum bileşiklerinin çeşitli farmakolojik etkileri vardır ve tüm kanıtlar, vanadyum bileşiklerinin etkilerinin, başta doz ve hücre tipi olmak üzere birçok faktöre bağıı olduğunu ortaya koymaktadır. Vanadyum bileșiklerinin proapoptotik veya antiapoptotik etkisi esas olarak hücre türüne bağııdır.

Gereç ve Yöntemler: Bu çalıșmada, çeșitli kanser hücre hatlarında; kolorektal kanser hücre hattı (Colo-205), insan meme adenokarsinoma hücre hattı (MCF-7) ve normal insan fibroblast hücre hattı kullanılarak vanadyum pentoksidin $\left(\mathrm{V}_{2} \mathrm{O}_{5}\right)$ sitotoksik aktivitesi araştırıldı. Sitotoksik etkilerini incelemek için $\mathrm{V}_{2} \mathrm{O}_{5} 25-200 \mu \mathrm{M}$ arasında 5 farklı konsantrasyonda hücrelere uygulandı ve empedans değişikliklerini değerlendirmek için xCELLigence gerçek zamanlı hücre analizi yapıldı. Bu çalışma, $\mathrm{V}_{2} \mathrm{O}_{5}$ 'in Colo-205, MCF-7 ve insan fibroblast hücre hatlarındaki etkilerini gerçek zamanlı olarak gösteren ilk çalışmadır.

Bulgular: $\mathrm{V}_{2} \mathrm{O}_{5}$, normal insan fibroblastında 12 saat sonuçlarına göre tüm konsantrasyonlarda Colo-205 ve MCF-7'den daha düşük sitotoksik etki gösterdi. Sağlıklı fibroblast hücre hattında, cell indeks (Cl) kontrol ile karșılaștırıldığında tüm konsantrasyonlarda azaldı. Colo-205 hücre hattında $\mathrm{Cl}, 25$ $\mu \mathrm{M}$ ve $50 \mu \mathrm{M}$ 'de azaldı; $100 \mu \mathrm{M}, 150 \mu \mathrm{M}$ ve $200 \mu \mathrm{M}$ konsantrasyonlarında arttı. MCF-7 hücre hattında, Cl kontrole kıyasla tüm konsantrasyonlarda arttı. Sonuç: Konvansiyonel anti-kanser ilaçlar ile kombinasyonu, kanser türü ve evreleri dikkate alınarak bu ilaçların yan etkilerini azaltmak ve etkinliği artıırmak için kullanılabilir. Bulgularımız; $\mathrm{V}_{2} \mathrm{O}_{5}$ 'in farklı konsantrasyonlarda çeşitli kanser hücreleri üzerinde farklı etkilere sahip olduğunu düșündürmektedir.

Anahtar kelimeler: xCELLigence, Colo-205, MCF-7, insan fibroblast hücre hattı, vanadyum pentoksit

*Correspondence: E-mail: ecz_ebru_ozturk@hotmail.com, Phone: +90 35220766 66/28276 ORCID-ID: orcid.org/0000-0002-7088-7490

Received: 13.01.2017, Accepted: 09.03.2017

Turk J Pharm Sci, Published by Galenos Publishing House. 


\section{INTRODUCTION}

Cancer is a disease in which the control of growth is lost in one or more cells, leading either to a solid mass of cells known as a tumor or to a liquid cancer. It is one of the leading causes of death throughout the world. ${ }^{1}$ Colorectal carcinoma is the most common gastrointestinal neoplasm and the second highest cause of death from cancer in the western world. In spite of recent advances in neoadjuvant therapeutic modalities, treatment success is limited in advanced stages of colorectal carcinoma. ${ }^{2}$ Breast cancer has become the most prevalent cancer and the leading cause of death among women worldwide despite the fact that available therapeutics have successfully controlled breast cancer mortality, particularly in advanced countries. ${ }^{3}$

Vanadium ( $V$ ) is a trace element that is present in the mammalian body. Recent studies have shown that both inorganic compounds of vanadium (IV) or $\mathrm{V}$ and their complexes with organic ligands, in which $V$ valencey may vary from III to $V$, exhibit cytostatic activity and suppress tumor cell growth in vitro and in vivo. ${ }^{4}$ Studies on various cell lines revealed that $V$ exerts its antitumor effects by means of inhibition of cellular tyrosine phosphatases and/or activation of tyrosine phosphorylases. Both effects activate signal transduction pathways leading either to apoptosis and/or to activation of tumor suppressor genes. Moreover, V compounds (VCs) may induce cell-cycle arrest and/or cytotoxic effects through DNA cleavage and fragmentation, and plasma membrane lipoperoxidation. $V$ may also exert inhibitory effects on cancer cell metastatic potential via modulation of cellular adhesive molecules and reverse antineoplastic drug resistance. ${ }^{5}$

In different cancer cell lines, some VCs acted as inhibitors of cell proliferation in the whole range of tested concentrations. These VCs were then evaluated as potentially antitumor agents. ${ }^{6}$ $\mathrm{V}$ pentoxide $\left(\mathrm{V}_{2} \mathrm{O}_{5}\right)$ was appointed to be studied by the National Cancer Institute as a representative of the metals class. ${ }^{7}$ It is obvious that tumor cells could be treated with various metal oxide nanoparticles, and specifically, $\mathrm{V}_{2} \mathrm{O}_{5}$ nanoparticles have an admirable potential due to the high cytotoxicity and antitumor effects of $V$. Vanadium oxides could be more toxic than $V$ salts. Additionally, it has been shown that the same VCs could possess selective cytotoxicity to various cell lines. ${ }^{8}$

The Roche xCELLigence real-time cell analysis (RTCA) system provides incessant, quantitative, and real-time monitoring of cells based on impedance measurements for analyzing the status of adherent cells in vitro. The measurement of electrical impedance gives an idea about the adherence, proliferation, and migration of cells. The changes observed in impedance due to cell attachment and spreading are expressed as the cell index (CI). The $\mathrm{Cl}$ reflects cell viability; cell number, attachment quality, and cell morphology. ${ }^{9.10}$ Monitoring of cell viability is critical and the xCELLigence system enables continuous measurement and quantification of cells."1 Also, time-dependent physiologic inhibitory concentration $\left(\mathrm{IC}_{50}\right)$ values can be calculated. It is a more reliable test because classic toxicity tests measure single $\mathrm{IC}_{50}$ end-points at one time point. ${ }^{10}$

The present study was designed to detect impedance alterations reflecting the cytotoxicity of $\mathrm{V}_{2} \mathrm{O}_{5}$ on different cell lines. The $x$ CELLigence technology was chosen because it has been used previously for monitoring cell viability in real time. ${ }^{9}$ In this study we investigated the effect of the compound on the growth of a colorectal cancer cell line (Colo-205), a human breast adenocarcinoma cell line (MCF-7), and also a normal human fibroblast cell line at different doses in vitro. This study is the first to show $\mathrm{V}_{2} \mathrm{O}_{5}$ 's effects on Colo-205, MCF-7, and human fibroblast cell lines in a real-time manner.

\section{EXPERIMENTAL}

\section{Chemicals}

Trypsin-ethylenediaminetetraacetic acid (EDTA) (T3924), fetal bovine serum (FBS, F2442), penicillin-streptomycin (P4333), $\mathrm{V}_{2} \mathrm{O}_{5}$ (CAS Number: 1314-62-1), Dulbecco's Modified Eagle's Medium (DMEM, D5546) were purchased from Sigma Aldrich.

\section{Cell culture}

MCF-7 [American Type Culture Collection (ATCC), HTB-22] human breast cancer cell line, Colo-205 (CCL-222) human Colo205 purchased from ATCC. Human fibroblast cell line gifted to us from GENKOK (Kayseri/Turkey). MCF-7 (12.500 cells/well) and Colo-205 (12.500 cells/well) cells cultured with DMEM containing FBS 10\%, L-glutamin 1\%, $100 \mathrm{U} / \mathrm{mL}$ penicillin and $100 \mu \mathrm{g} / \mathrm{mL}$ streptomycin. Human fibroblast cells (3000 cells/ well) cultured with DMEM containing FBS 20\%, L-glutamin $1 \%, 100 \mathrm{U} / \mathrm{mL}$ penicillin and $100 \mu \mathrm{g} / \mathrm{mL}$ streptomycin. The cells were grown to $80 \%$ confluence at $37^{\circ} \mathrm{C}$ and humidified in an atmosphere with $5 \% \mathrm{CO}_{2}$. When cells reached approximately $80 \%$ confluence, we detached cells with $0.25 \%$ trypsin-EDTA. The cells were centrifuged using a Universal 320R (Hettich, Zentrifugen, 1406 Germany) at $1000 \mathrm{rpm}$ for $5 \mathrm{~min}$ at $25^{\circ} \mathrm{C}$ and seeded on a 96-well E-plate for xCELLigence analysis. When the cells reached the log growth phase approximately $24 \mathrm{~h}$ later from seeding to E-plate, we treated the cells with $\mathrm{V}_{2} \mathrm{O}_{5}$ for 25 , $50,100,150,200 \mu \mathrm{M}$ concentrations.

\section{Xcelligence real-time cell analysis}

The cytotoxic effect of $\mathrm{V}_{2} \mathrm{O}_{5}$ was monitored using an xCELLigence RTCA as described by manufacturer's instructions (Roche Applied Science and ACEA Biosciences) with slight modifications. First, optimal seeding concentrations of MCF7, Colo-205, and fibroblast cells were determined and then the cells were seeded in 96- well E-plates. Cell proliferation, attachment, and spreading were monitored every $15 \mathrm{~min}$ via the impedance of the E-plate wells. Approximately $24 \mathrm{~h}$ postseeding, when the cells were in the log growth phase, we treated cells with $\mathrm{V}_{2} \mathrm{O}_{5}$ and controls received only medium and replicated 4-times; the experiments were run for about $72 \mathrm{~h}$.

Cell growth and proliferation assay using the xcelligence system At the end of the experiment, all calculations were made using 
the integrated software of the xCELLigence RTCA system (Figure 1). A unitless parameter termed $\mathrm{Cl}$ is derived to represent cell status based on the measured relative change in electrical impedance that occurs in the presence and absence of cells in the wells, which is calculated based on the following formula: $\mathrm{Cl}=\left(\mathrm{Zi}-\mathrm{Z}_{0}\right) / 15$, where $\mathrm{Zi}$ is the impedance at an individual point of time during the experiment, and $Z_{0}$ is the impedance at the start of the experiment (Figure 2). The RTCA software performs the curve-fitting of the selected "sigmoidal doseresponse equation" and calculated logarithmic half maximum effect of concentration $\left[\log \left(\mathrm{IC}_{50}\right)\right]$ values at a given time points based on log concentrations producing a $50 \%$ reduction of $\mathrm{Cl}$ value relative to the control $\mathrm{Cl}$ value (100\%).
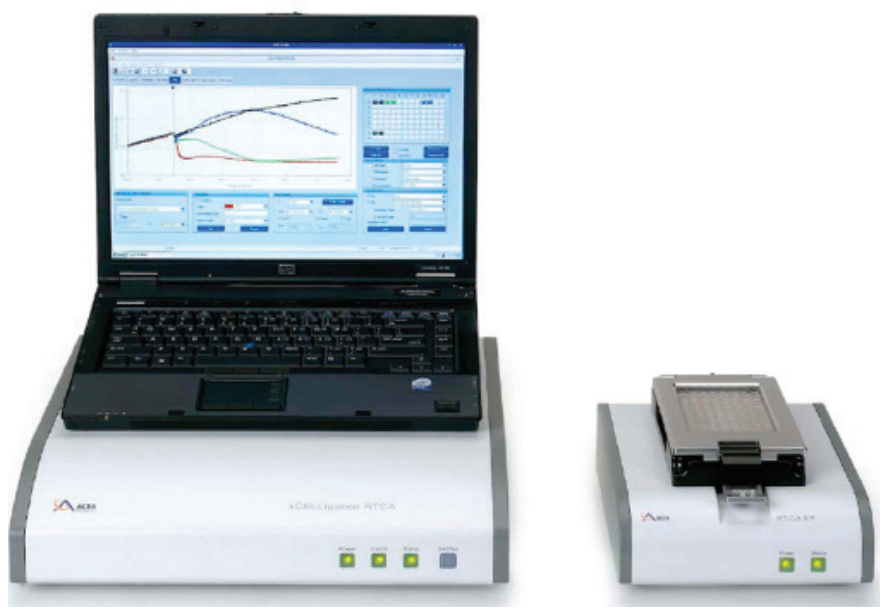

Figure 1. xCELLigence real time cell analyser single plate $\mathrm{e}^{10}$

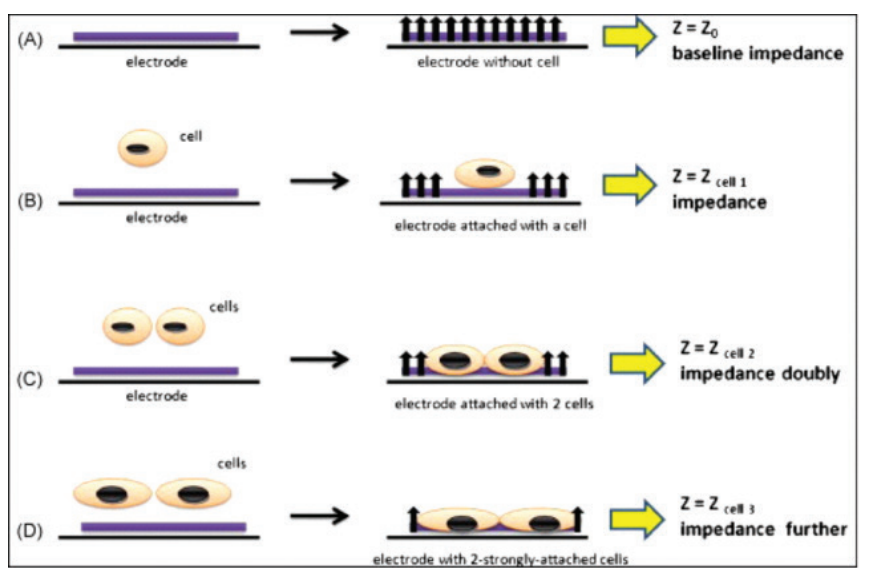

Figure 2. Scheme of $x$ CELLigence impedance alteration ${ }^{10}$

Baseline impedance: No cells on an electrode surface (A). Impedance: A cell attaches to the electrode surface and partially blocks the electrical current in the circuit, inducing an increase in the electrode impedance (B). Impedance doubly: Two cells attach to the electrode surface and even further reduce the electrical current, as compared with $\mathrm{B}$, inducing doubly-increased impedance (C). Impedance further: Two cells attach to the electrode surface with more extension, which induces much more impedance in comparison with C (D)

\section{Statistical analysis}

For each study group, data were derived from at least three independent experiments. Statistical analysis was performed using the GraphPad Prism Software Version 5.03 using Sidak's multiple comparisons test to compare differences in values between the control and experimental group. Data are expressed as mean \pm standard deviation. Values of all significant correlations $(p<0.05)$ are given with degrees of significance indicated $\left({ }^{*} p<0.01,{ }^{* *} p<0.001,{ }^{* * *} p<0.0001,{ }^{* * * *} p<0.00001\right)$.

\section{RESULTS}

The xCELLigence system was used to analyse impedance alterations by the cytotoxic effect of $\mathrm{V}_{2} \mathrm{O}_{5}$ on normal human fibroblast, Colo-205 and MCF-7 cell lines. Normal human fibroblasts, Colo-205, and MCF-7 cell lines were exposed to $\mathrm{V}_{2} \mathrm{O}_{5} 25 \mu \mathrm{M}, 50 \mu \mathrm{M}, 100 \mu \mathrm{M}, 150 \mu \mathrm{M}$ and $200 \mu \mathrm{M}$ for $72 \mathrm{~h} . \mathrm{V}_{2} \mathrm{O}_{5}$ exhibited a cytotoxic effect on normal human fibroblasts at 25 $\mu \mathrm{M}, 50 \mu \mathrm{M}, 100 \mu \mathrm{M}, 150 \mu \mathrm{M}$, and $200 \mu \mathrm{M}$ concentrations (Figure 3). In the healthy fibroblast cell line, the $\mathrm{Cl}$ alterations decreased at all concentrations compared with the untreated control (Figure 4). In the Colo-205 cell line, the $\mathrm{Cl}$ alterations decreased slightly at $25 \mu \mathrm{M}$ and $50 \mu \mathrm{M}$, and increased at $100 \mu \mathrm{M}, 150 \mu \mathrm{M}$, and $200 \mu \mathrm{M}$ concentrations (Figure 5 and Figure 6). In the MCF7 cell line, the $\mathrm{Cl}$ alterations increased at all concentrations compared with the untreated control (Figure 7 and Figure 8). The $\mathrm{IC}_{50}$ values obtained in the studied concentrations for 12 $\mathrm{h}$ and $24 \mathrm{~h}$ incubations in these cell lines are shown in Table 1.

\section{Table 1. IC $\mathrm{C}_{50}$ values for $\mathrm{V}_{2} \mathrm{O}_{5}$}

\begin{tabular}{lll} 
Cell line & $\mathrm{IC}_{50} 12 \mathrm{~h}$ & $\mathrm{IC}_{50} 24 \mathrm{~h}$ \\
\hline Human fibroblast cells & $136.741 \mu \mathrm{M}$ & $101.18 \mu \mathrm{M}$ \\
\hline Colo-205 & $118.58 \mu \mathrm{M}$ & $145.29 \mu \mathrm{M}$ \\
\hline MCF-7 & $64.14 \mu \mathrm{M}$ & $219.82 \mu \mathrm{M}$ \\
\hline
\end{tabular}

$\mathrm{V}_{2} \mathrm{O}_{5}$ : Vanadium pentoxide, Colo-205: Colorectal cancer cell line, $\mathrm{IC}_{50}$ : Inhibitory concentration

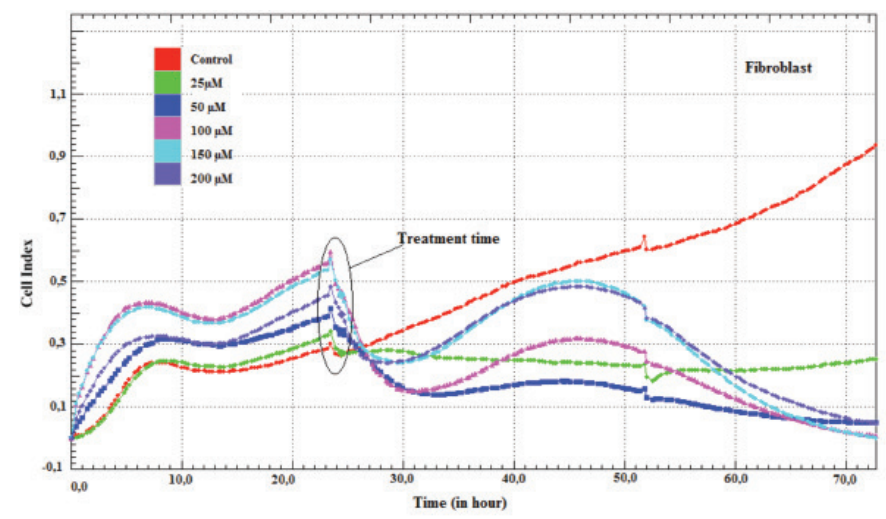

Figure 3. Dynamic monitoring of fibroblast cell adhesion and proliferation using the XCELLigence system. Fibroblast at a density of 3000 cells/well in E-plates were observed over $72 \mathrm{~h}$ 


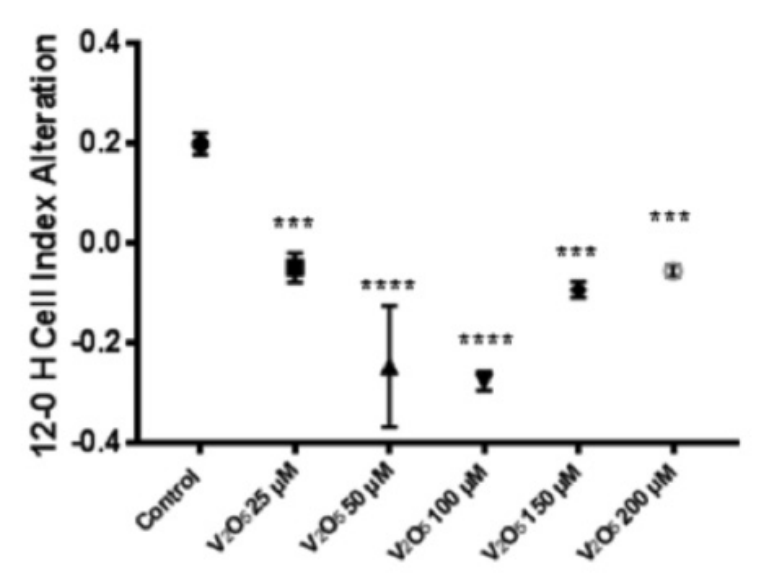

Figure 4. $\mathrm{Cl}$ alterations after $12 \mathrm{~h}$ incubation of the healthy fibroblast cell line by $\mathrm{V}_{2} \mathrm{O}_{5}$ treatment. Data were calculated from three independent experiments. Data are presented as mean \pm standard deviation, ${ }^{\star * *} p<0.0001$ and ${ }^{* * *} p<0.00001$ compared with the untreated control

$\mathrm{V}_{2} \mathrm{O}_{5}$ : Vanadium pentoxide, $\mathrm{Cl}$ : Cell index

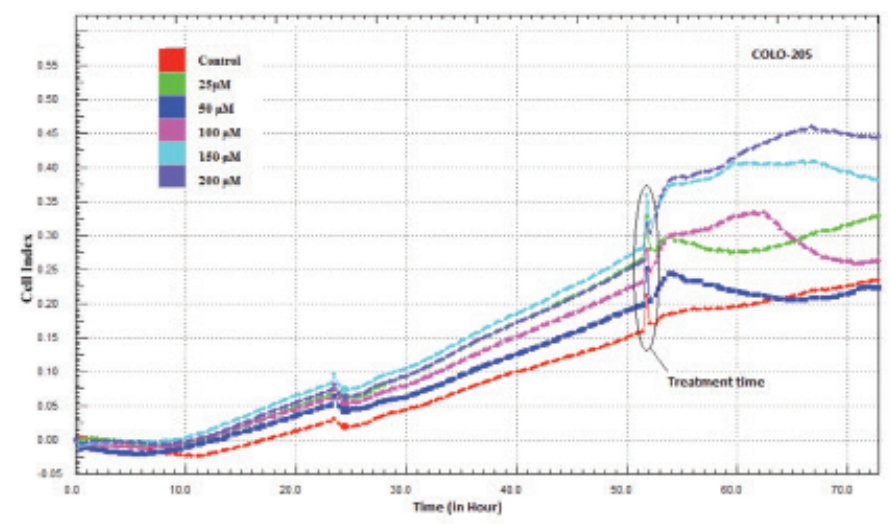

Figure 5. Dynamic monitoring of Colo-205 cell adhesion and proliferation using the xCELLigence system. Colo-205 at a density of 12.500 cells/well in E-Plates were observed over $72 \mathrm{~h}$

Colo-205: Colorectal cancer cell line

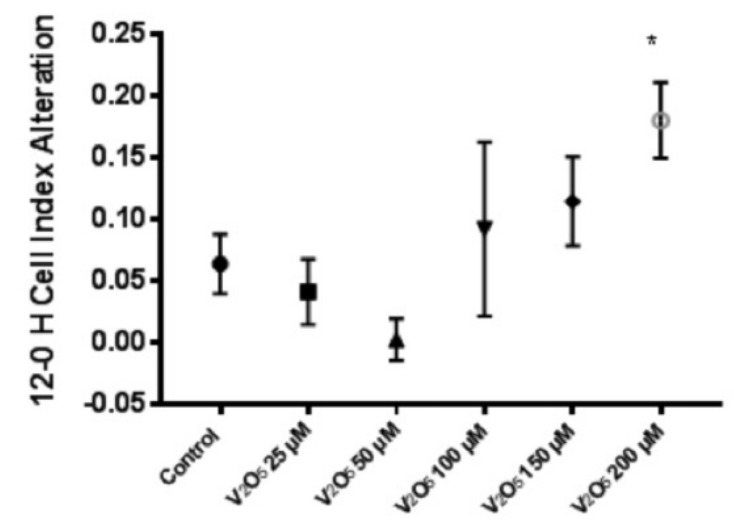

Figure 6. $\mathrm{Cl}$ alterations after $12 \mathrm{~h}$ incubation of the Colo-205 cell line by $\mathrm{V}_{2} \mathrm{O}_{5}$ treatment. Data are presented as mean \pm standard deviation, ${ }^{*} \mathrm{p}<0.01$ compared with the untreated control

Colo-205: Colorectal cancer cell line, $\mathrm{V}_{2} \mathrm{O}_{5}$ : Vanadium pentoxide

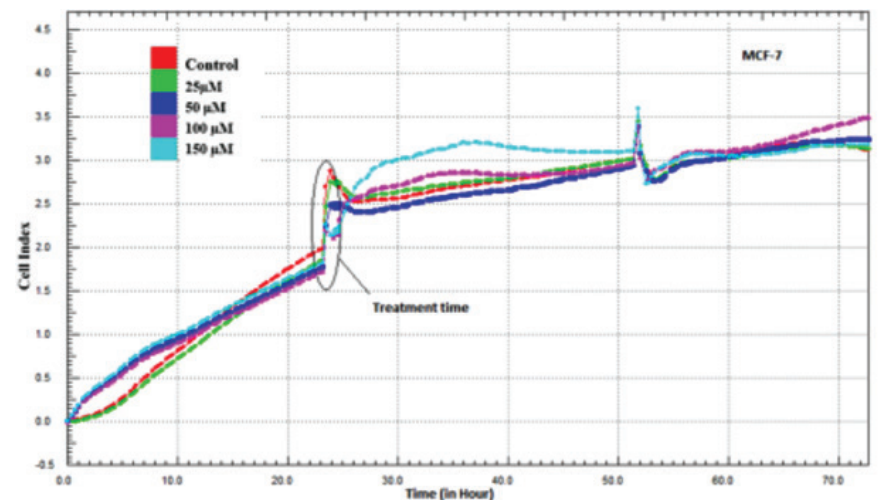

Figure 7. Dynamic monitoring of MCF-7 cell adhesion and proliferation using the XCELLigence system. MCF-7 at a density of 12.500 cells/well in E-Plates were observed over $72 \mathrm{~h}$

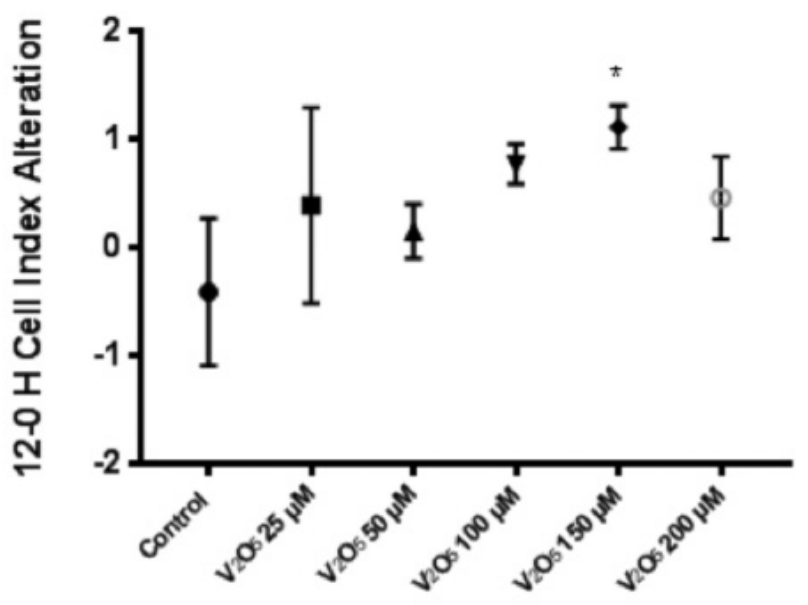

Figure $8 . \mathrm{Cl}$ alterations after $12 \mathrm{~h}$ incubation of the MCF-7 cell line by $\mathrm{V}_{2} \mathrm{O}_{5}$ treatment. Data are presented as mean \pm standard deviation, ${ }^{*} p<0.01$, compared with the untreated control

$\mathrm{V}_{2} \mathrm{O}_{5}$ : Vanadium pentoxide

\section{DISCUSSION}

Metallodrugs in particular represent new and powerful tools for diverse therapeutic applications. To date, various metallodrugs have shown interesting biologic activities for chemotherapy. In this field, cisplatin was the first inorganic compound with high relevance in cancer treatment. This compound was a leader agent in clinical use. Toxicity and resistance problems triggered the development of other platinum drugs with better clinical perspective and also raised scientific interest in the putative antitumor properties of VCs. Various scientific articles reviewed by León et al..$^{12}$ showed that complexes of these metals were the new metal-based drugs used in the treatment of several cancers, such as lung, colon, breast, and bladder cancer. Vanadate is a transition element that is present in nature and was shown to be a nonspecific inhibitor of protein tyrosine phosphatases. VCs exhibit antitumor actions in several cancer cell lines. ${ }^{12,13}$ 
The xCELLigence RTCA equipment uses specific microtiter E-plates coated with gold-microelectrodes that detect the attachment of adherent cells, thus modifying the impedance signal. The xCELLigence RTCA is a non-invasive, impedancebased biosensor system that can measure cell viability, migration, growth, spreading, and proliferation. Alterations in cell morphology and behavior are continuously monitored in real-time using microelectronics located in the wells of RTCA E-plates. As shown previously, the xCELLigence system is wellsuited to analyze drug effects on cell proliferation, cytostasis, and cytotoxicity in real-time. In comparison with single endpoint assays, the availability of drug effect profiles over the whole experimental period allows building of dynamic growth curves. To evaluate the utility of this system for analysis of targeted therapies, Ruiz et al..$^{14}$ subjected two established nonsmall cell lung cancer cell lines, H522 and H3122, to crizotinib treatment. The real-time monitoring system allowed them to determine the latency time of the drug effect on cell growth.

Tumor cell lines with various proliferative rates were equally sensitive to orthovanadate cytotoxicity. Sodium orthovanadate $\left(\mathrm{Na}_{3} \mathrm{VO}_{4}\right)$ at concentrations greater than $5 \mu \mathrm{M}$ has antineoplastic properties in vitro and in vivo. ${ }^{15}$ Within the concentration range of 1-20 $\mu \mathrm{M}, \mathrm{Na}_{3} \mathrm{VO}_{4}$ demonstrated a time- and dose-dependent inhibition of autocrine growth of the human carcinoma cell lines A549 (lung), HTB44 (kidney) and DU145 (prostate), as compared with appropriate controls (without $\mathrm{Na}_{3} \mathrm{VO}_{4}$ ). Klein et al. ${ }^{16}$ also revealed that HTB44, A549, and DU15 cell lines had different sensitivity to $\mathrm{Na}_{3} \mathrm{VO}_{4}$. Kordowiak et al. ${ }^{17}$ showed progressive growth inhibition of rat hepatoma H35-19 cells within the range 0.5-20.0 $\mu \mathrm{M}$ concentrations of three $V$ salts. The most effective (and/or toxic) was sodium metavanadate $\left(\mathrm{NaVO}_{3}\right)$, whereas vanadyl sulfate showed a relatively mild action. As compared with metavanadate or vanadyl sulphate, and especially organic $V$ derivatives, previously studied by the same authors under similar experimental conditions, $\mathrm{Na}_{3} \mathrm{VO}_{4}$ showed an intermediate effect. ${ }^{17}$ Yang et al. $^{13}$ demonstrated that sodium vanadate had cytotoxic effects on esophageal squamous carcinoma cell line EC109 at $50 \mu \mathrm{M}$. The antiproliferative effect of bis(acetylacetonato)oxidovanadium(IV) and $\mathrm{NaVO}_{3}$ and the underlying mechanisms were investigated in the human pancreatic cancer cell line AsPC1. VCs can be regarded as a novel type of anticancer drug through the prolonged activation of the mitogen-activated protein kinase/ extracellular signal-regulated kinase pathway but retained AKT activity. ${ }^{18} \mathrm{~V}$ has no carcinogenic effect but its presence in cancer cells and its interactions with many key enzymatic processes results in modified expression of p53 and Bax and in down-regulation of $\mathrm{Bcl}-2$ proteins and in antiproliferative activity. The anticancer effects of $\mathrm{V}$ in various forms have been demonstrated using in vitro and in vivo experiments. ${ }^{19}$ VCs were introduced into therapy due to their low $\mathrm{IC}_{50}$, and antiproliferative and proapoptotic effects. Additionally, VCs stimulate the cell cycle, thereby inhibiting apoptosis, because both processes are mutually related. The above processes promote tumor cell growth at early stages of the disease and have an antitumor effect in the advanced stages of cancer. VCs used at low concentrations had selective effects on tumor cells in in vivo and in vitro studies. The effects of VCs depend on many factors, mainly on the type of cells, the type of VC, and its dose. It appears that the proapoptotic or antiapoptotic effect of VCs depends strongly on the cell type. ${ }^{20}$

In our study, we investigated the effects of $\mathrm{V}_{2} \mathrm{O}_{5}$ on three different cell lines, including human fibroblast cells, MCF7, and Colo-205. In the Colo-205 cell line, $\mathrm{Cl}$ alterations decreased slightly at 25 $\mu \mathrm{M}$ and $50 \mu \mathrm{M}$, and increased at $100 \mu \mathrm{M}, 150 \mu \mathrm{M}$ and $200 \mu \mathrm{M}$ concentrations. In the MCF-7 cell line, $\mathrm{Cl}$ alterations increased at all concentrations compared with the untreated control. In the human fibroblast cell line, $\mathrm{Cl}$ alterations decreased at all concentrations. Our results suggest that although $\mathrm{V}_{2} \mathrm{O}_{5}$ causes toxicity on human fibroblast cells, it also shows an antiproliferative effect at 25 and $50 \mu \mathrm{M}$ concentrations and a proliferative effect at high concentrations on Colo-205, and a proliferative effect on MCF-7 cell lines at all concentrations used.

\section{CONCLUSION}

VCs have various pharmacologic effects and affect various biochemical processes, and all evidence suggests that the effects of VCs depend on many factors, mainly on the type of cells and their doses. It appears that the proapoptotic or antiapoptotic effect of VCs depends largely on the cell type. Our results are important for further mechanism of action studies because we have shown that trace amounts of $\mathrm{V}_{2} \mathrm{O}_{5}$ with conventional therapies might strengthen or weaken the impact of the treatment. Additional mechanism-of-action studies should be performed to confirm the beneficial and toxic effects of $\mathrm{V}_{2} \mathrm{O}_{5}$ in different experiments and cancer cell types at high or low doses. Combinations of conventional anticancer drugs can be used to increase the effectiveness and reduce the adverse effects of these drugs with consideration to the stages of cancer and cancer type. Our results suggest that $\mathrm{V}_{2} \mathrm{O}_{5}$ has disparate effects on several cancer cells at different concentrations. This study is the first to show $\mathrm{V}_{2} \mathrm{O}_{5}$ 's effects on Colo-205, MCF-7, and human fibroblast cell lines in a real-time manner.

\section{ACKNOWLEDGEMENT}

The project received no financial support.

Conflict of interest: The authors declare that there are no conflicts of interest.

\section{REFERENCES}

1. Nussbaumer S, Bonnabry P, Veuthey JL, Fleury-Souverain S. Analysis of anticancer drugs: a review. Talanta. 2011;85:2265-2289.

2. Reuveni D, Halperin D, Shalit I, Priel E, Fabian I. Moxifloxacin enhances etoposide-induced cytotoxic, apoptotic and anti-topoisomerase II effects in a human colon carcinoma cell line. Int J Oncol. 2010;37:463-471.

3. Wei H, Fu P, Yao M, Chen Y, Du L. Breast cancer stem cells phenotype and plasma cell-predominant breast cancer independently indicate poor survival. Pathol Res Pract. 2016;212:294-301. 
4. Abakumova Oyu, Podobed OV, Belayeva NF, Tochilkin Al. Anticancer activity of oxovanadium compounds. Biochem (Mosc) Biomed Chem Suppl Ser. 2012;6:164-170.

5. Evangelou AM. Vanadium in cancer treatment. Crit Rev Oncol Hematol. 2002;42:249-265.

6. Pessoa JC, Etcheverry S, Gambino D. Vanadium compounds in medicine. Coordin Chem Rev. 2015;301:24-48.

7. National Toxicology Program. NTP toxicology and carcinogensis studies of vanadium pentoxide (CAS No. 1314-62-1) in F344/N rats and B6C3F1 mice (inhalation). Natl Toxicol Program Tech Rep Ser. 2002:1-343.

8. Ivankovic S, Music S, Gotic M, Ljubešic N. Cytotoxicity of nanosize V2O5 particles to selected fibroblast and tumor cells. Toxicol in vitro. 2006;20:286-294.

9. Keogh RJ. New technology for investigating trophoblast function. Placenta 2010;31:347-350.

10. Urcan E, Haertel U, Styllou M, Hickel R, Scherthan H, Reichl FX. Real-time xCELLigence impedance analysis of the cytotoxicity of dental composite components on human gingival fibroblasts. Dent Mater. 2010;26:51-58.

11. Golke A, Cymerys J, Stonska A, Dzieciatkowski T, Chmielewska A, Tucholska A, Banbura MW. The xCELLigence system for real-time and label-free analysis of neuronal and dermal cell response to Equine Herpesvirus type 1 infection. Pol J Vet Sci. 2012;15:151-153.

12. León IE, Cadavid-Vargas JF, Di Virgilio AL, Etcheverry SB. Vanadium, Ruthenium and Copper Compounds: A New Class of Nonplatinum Metallodrugs with Anticancer Activity. Curr Med Chem. 2017;24:112-148.
13. Yang J, Zhang Z, Jiang S, Zhang M, Lu J, Huang L, Zhang T, Gong K, Yan S, Yang Z, Shao G. Vanadate-induced antiproliferative and apoptotic response in esophageal squamous carcinoma cell line EC109. J Toxicol Environ Health A. 2016;79:864-868.

14. Ruiz C, Kustermann S, Pietilae E, Vlajnic T, Baschiera B, Arabi L, Lorber T, Oeggerli M, Savic S, Obermann E, Singer T, Rothschild SI, Zippelius A, Roth AB, Bubendorf L. Culture and Drug Profiling of Patient Derived Malignant Pleural Effusions for Personalized Cancer Medicine. PloS One. 2016;11:e0160807.

15. Cruz TF, Morgan A, Min W. In vitro and in vivo antineoplastic effects of ortrovanadate. Mol Cell Biochem. 1995;153:161-166.

16. Klein A, Holko P, Ligeza J, Kordowiak AM. Sodium orthovanadate affects growth of some human epithelial cancer cells (A549, HTB44, DU145). Folia Biol (Krakow). 2008;56:115-121.

17. Kordowiak AM, Klein A, Goc A, Dabros W. Comparison of the effect of VOSO4, Na3VO4 and NaVO3 on proliferation, viability and morphology of H35-19 rat hepatoma cell line. Pol J Pathol. 2007;58:51-57.

18. Wu JX, Hong YH, Yang XG. Bis (acetylacetonato)-oxidovanadium (IV) and sodium metavanadate inhibit cell proliferation via ROS-induced sustained MAPK/ERK activation but with elevated AKT activity in human pancreatic cancer AsPC-1 cells. J Biol Inorg Chem. 2016;21:919-929.

19. Novotny L, Kombian SB. Vanadium: possible use in cancer chemoprevention and therapy. J Can Res Updates. 2014;3:97-102.

20. Korbecki J, Baranowska-Bosiacka I, Gutowska I, Chlubek D. Biochemical and medical importance of vanadium compounds. Acta Biochim Pol. 2012;59:195-200. 